\title{
Microbial profile of common spices and spice blends used in Tamale, Ghana
}

\author{
Noel Bakobie ${ }^{1}$, Amponsah Samuel Addae ${ }^{1}$, Abudu Ballu Duwiejuah ${ }^{1,2^{*}}$, Samuel Jerry Cobbina ${ }^{1}$ \\ and Solomon Miniyila ${ }^{3}$
}

\begin{abstract}
Background: The main purpose of using spice to grill meat is to add aroma, colour, flavour, taste and pungency. However, the purpose is sometime befitted when spice is contaminated with pathogenic bacteria that result in foodborne illnesses and toxicological effect.

Results: The study was necessitated by paucity information on handling practices and microbial load common spices used for grilling meat, Ghana. A total of twenty spice samples were collected from five popular and widely patronised joints in the Tamale in Ghana. Detection and identification of potential pathogens was carried out following standard procedures. E. coli count ranged from 0 to $3.14 \log _{10} \mathrm{cfu} / \mathrm{ml}$ with a mean of $1.17 \pm 1.07 \log _{10} \mathrm{cfu} / \mathrm{ml}$. Contamination level for Salmonella spp ranged between 0 and $0.9 \log _{10} \mathrm{cfu} / \mathrm{ml}$ with a mean of $0.38 \pm 0.31 \log _{10} \mathrm{cfu} / \mathrm{ml}$. Coliform bacteria were present in almost all the spices sampled. Faecal coliform and $E$. coli presence was an indication of contamination by fresh faecal matter. The possible sources of spice contamination include storage equipment, handling, unhygienic surroundings, vehicular transmission, atmospheric particles and air-microbes.

Conclusions: There is a possible risk to public health associated with consumption of spicy meat from the selected joints. There is the need to maintain good sanitary practice and hygienic quality during production stages of spice in order to avoid or reduce prevalence of food borne illnesses in Tamale and Ghana as a whole.
\end{abstract}

Keywords: Contamination, foodborne illness, pathogenic bacteria, spice, Ghana

\section{Background}

Street food is sold in every nook and cranny of major towns and cities in both developed and developing countries. Street foods are mostly prepared in open-air public spaces either stationary or itinerant, either on foot or from mobile outlets, removable outlets, and fixed outlets without enclosed space by food vendors to accommodate consumers (Food and Agriculture Organization of the United Nations 2016). Street food vending and consumption have recently flourished for some decades in Africa largely due to increase in urban population and wide spread of urban boundaries and urban sprawl (Food and Agriculture Organization of the United Nations 2016).

\footnotetext{
* Correspondence: abalu096@gmail.com

${ }^{1}$ Department of Ecotourism and Environmental Management, Faculty of Natural Resources and Environment, University for Development Studies, Tamale, Ghana

${ }^{2}$ Department of Biotechnology, Faculty of Agriculture, University for

Development Studies, Tamale, Ghana

Full list of author information is available at the end of the article
}

Food safety is a concern for the general public as almost everybody for the past year has ever suffered from foodborne illnesses at least once (WHO 2015). Diarrhoea has been one of the major causes of hospital attendance in Ghana, and 16\% deaths of children younger than five years in African (Bruce et al. 2005). Food-borne disease outbreaks due to importation were reported to have increased between 2009 and 2010 in which fish and spice were the most common sources (Centre for Disease Control CDC 2012).

Most of these street foods are sold to consumers with spices that are traditionally or locally prepared. Spices are group of food additives utilised to enhance sensory quality of some foods by making those foods more palatable (DebsLouka et al. 2013). Sodium and fat content is very low in spice causing the increased in their consumption (Srinivasan 2005). However, conditions under which they are produced and basic operations such as drying, harvesting, threshing, transport and storage are potential sources of contamination with bacteria, fungi and insects (Alam-Khan and Abrahem 2010; Sádecká 2007). This can lead to an increase in certain 
foodborne illnesses and intoxications (Buckenhuskes and Rendlen 2004) and food spoilage (Ahene et al. 2011).

Spice has low moisture content making it safe, but when in contact with some food products that has high water, microbial populations could be stimulated because of increase in water activity (Menlove and Sainsbury 2002). The interventions in production process are mostly based on reduction or elimination of some contamination by means of heat treatment (Zwietering et al. 2016).

Generally, in Ghana, mix-powdered spice is usually used in grilling meat such as chevon, chicken, guinea fowl, suya (dried smoke meat), pork and many more which are processed manually and sold to general public at various lorry terminals, by roadside or itinerant vendors (Mensah et al. 2002). A study by Addo (2005) reported fungal count of $3.08 \log _{10} \mathrm{cfu} / \mathrm{g}$ to $2.40 \log _{10} \mathrm{cfu} / \mathrm{g}$ in the ginger samples. Also, the total aerobic bacteria count in the spice ranged from $3.6 \log _{10} \mathrm{cfu} / \mathrm{g}$ in ginger sample to $3.7 \log _{10} \mathrm{cfu} / \mathrm{g}$ sample (in mixture of ginger and garlic) bacteria species which collectively contaminated the spice were Enterobacter spp, Aeromonas salmonicida and Salmonella spp. Sagoo et al. (2009) and Shamsuddeen (2009) also reported potential public health risk of spices and herbs after isolating high counts of Bacillus cereus, Clostridium perfrigens and Escherichia coli. Spices are usually sold as loose or packed in the local markets and consumed in cities, towns and countryside of Ghana. The study was necessitated by paucity information on handling practices and microbial load on common spices used for grilling meat, Ghana.

\section{Methods}

\section{Study area}

The research was carried out in the central part of Tamale. Tamale is the capital city of the Northern Region of Ghana and lies in latitude $9^{\circ} 15^{\prime}$ and $9^{\circ} 05^{\prime} \mathrm{N}$ and in longitude $0^{\circ}$ $45^{\prime}$ and $1^{\circ} 0^{\prime} \mathrm{W}$ at an altitude of $185 \mathrm{~m}$ above sea level. It is third most populous settlement in Ghana with 537,986 inhabitants according to 2010 census (Ghana Statistical Service 2012). As a fast growing city, a lot of people migrate to Tamale to do businesses (Abankwa et al. 2009). It is a home to both locals and internationals.

\section{Sample collection and preparation}

A total of twenty spice samples were collected from five popular and widely patronised selected sites in Tamale. Four (4) samples were collected from each vendor on weekly basis for a period of one month (February to March, 2014). A small plastic container cleaned with methylated spirit was used to collect samples from the vendors. The samples were stored in a sterile box containing ice cubes and taken to the CSIR- Water Research Institute laboratory (Tamale) for analysis. Strict standard practices and aseptic conditions were observed to avoid possible contamination during sample collection and transportation, prior to analysis. Vendors of spicy meat were interviewed to ascertain possible sources of bacteria contaminant.

Using a sterilise spatula and weighing boat, five-grams of the spice samples were transferred into a sterile falcon tube with $45 \mathrm{ml}$ of sterile Phosphate Buffer Saline 10x water and vortexes for about $2 \mathrm{~min}$. It was then carefully swirled few times to ensure a homogenous mixture.

\section{Microbial of determination}

Microbiological analysis was done in accordance with American Public Health Association (APHA) (2008) standard procedures for analysis. A 3-fold serial dilution was performed for the enumeration of Salmonella spp, E. coli, total coliform, faecal coliform and Clostridium perfringens bacteria from spice samples. Hi-crome, MFC agar, M-Endo agar and Salmonella-Shigalla (SS) agar were used for detection of Escherichia coli, faecal coliform, total coliform and Salmonella spp, respectively whereas nutrient agar was used for Clostridium perfringens detection using pour plate method.

Faecal coliform was determined by filtering $60 \mathrm{ml}$ of sample through a 0.45 um filter onto a Petri dish containing MFC and incubated at $44 \pm 2{ }^{\circ} \mathrm{C}$ for $18-24 \mathrm{~h}$ and colonies were then counted. For detection for total coliform and Escherichia coli, sample was plated in M-Endo and Hichrome and incubated at $37 \pm 2{ }^{\circ} \mathrm{C}$ for $18-24 \mathrm{~h}$, respectively. Colonies of total coliform and $E$. coli were counted.

For Salmonella spp detection, $10 \mathrm{ml}$ of the supernatant was filtered after priming membrane filter with $10 \mathrm{ml}$ spice dissolved in water. Another $5 \mathrm{ml}$ of spice dissolved in water was further used to rinse inner sides of funnel. Membrane filter was then transferred onto SalmonellaShigalla agar for detection of the target microbes with the aid of a sterilised forceps. In Clostridium perfringens detection, $1 \mathrm{ml}$ of the supernatant derived from the wash of spice samples were aliquot into a test tube after being heated in a water bath for about $15 \mathrm{~min}$ at about $50 \pm 2^{\circ}$ C. Nutrient agars of about $20 \mathrm{ml}$ were poured into the Petri dish, and then swirled both clockwise and anticlockwise. Colonies were counted with a colony counter.

\section{Statistical analysis}

Analysis of variance (ANOVA) was deployed to determine significant difference between microbial loads from five popular meat grilling joints. Pearson's correlation matrix was also conducted before changing the microbial count values to a logarithmic scale.

\section{Results and Discussion}

To prevent occurrence of food borne illnesses, it is important to ensure foods safety and hygiene at every stage of food processing and selling. The present study recorded faecal coliform count that ranged between 0 and $3.4 \log _{10}$ $\mathrm{cfu} / \mathrm{ml}$ with a mean of $1.17 \pm 1.07 \log _{10} \mathrm{cfu} / \mathrm{ml}$ (Table 1 ). 
Table 1 Microbial load of spices used for grilling meat in the Tamale

\begin{tabular}{|c|c|c|c|c|c|}
\hline Sample Sites & TC & $\mathrm{FC}$ & E. coli & SS & C. perfringens \\
\hline A1 & 0 & 2.7 & 1.81 & 0.03 & 0 \\
\hline B1 & 0.9 & 1.63 & 0 & 0.44 & 0 \\
\hline $\mathrm{C} 1$ & 0 & 0 & 2 & 0.34 & 0 \\
\hline D1 & 0.31 & 0 & 1.76 & 0 & 0 \\
\hline E1 & 0.9 & 1.95 & 0.68 & 0.2 & 0 \\
\hline A2 & 0 & 2.13 & 1.43 & 0 & 0 \\
\hline B2 & 0 & 1.84 & 0 & 0 & 0 \\
\hline C2 & 1.66 & 0.8 & 2.32 & 0.46 & 0 \\
\hline D2 & 0.22 & 1.31 & 0 & 0.9 & 0 \\
\hline E2 & 0.9 & 0 & 0 & 0.47 & 0 \\
\hline A3 & 0.23 & 0.77 & 3.14 & 0.3 & 0 \\
\hline B3 & 1.7 & 2.4 & 0.54 & 0.3 & 0 \\
\hline C3 & 0 & 1.7 & 0 & 0.64 & 0 \\
\hline D3 & 0.69 & 0 & 1.9 & 0.5 & 0 \\
\hline E3 & 0.4 & 0.62 & 2.2 & 0 & 0 \\
\hline A4 & 1.04 & 0.32 & 2.6 & 0.9 & 0 \\
\hline B4 & 0.36 & 0 & 0.66 & 0.72 & 0 \\
\hline C4 & 0 & 0 & 1.51 & 0.4 & 0 \\
\hline D4 & 0.3 & 1.2 & 0 & 0.8 & 0 \\
\hline E4 & 0.5 & 0 & 0 & 0 & 0 \\
\hline Min & 0 & 0 & 0 & 0 & 0 \\
\hline Max & 1.7 & 2.7 & 3.14 & 0.9 & 0 \\
\hline Mean & 0.54 & 0.96 & 1.17 & 0.38 & 0 \\
\hline SD & 0.55 & 0.94 & 1.07 & 0.31 & 0 \\
\hline GSB (2006) & 0 & 0 & 0 & 0 & 0 \\
\hline WHO Limits (2011) & 0 & 0 & 0 & 0 & 0 \\
\hline
\end{tabular}

Note: All values are units of $\log _{10} \mathrm{cfu} / \mathrm{ml}$ : A-D: Samples sites and 1-4 means first to fourth sample

TC Total coliform, FC Faecal coliform, E. coli: Escherichia coli, SS Salmonella spp., C. perfringens Clostridium perfringens

Total coliform count ranged from 0 to $1.7 \log _{10} \mathrm{cfu} / \mathrm{ml}$ with a mean of $0.54 \pm 0.55 \log _{10} \mathrm{cfu} / \mathrm{ml}$ (Table 1). E. coli count ranged between 0 and $3.14 \log _{10} \mathrm{cfu} / \mathrm{ml}$ with a mean of $1.17 \pm 1.07 \log _{10} \mathrm{cfu} / \mathrm{ml}$ (Table 1 ).

Coliform bacteria were present in almost all the spice sampled. The faecal coliform and E. coli detected in the samples was an indication of contamination by fresh faecal matter. This might be due to inadequate hand washing by vendors and absence of good personal hygiene. This according to FDA (2011) can cause vibrio cholera, bloody diarrhoea, and kidney failure in children or people with weak immune system.

Most food poisoning is commonly cause by Salmonellae that are pathogens. Salmonellosis is principally a food borne disease (European Union EU 2004). Contamination level for Salmonella spp ranged from 0 to $0.9 \log _{10} \mathrm{cfu} /$ $\mathrm{ml}$ with a mean of $0.38 \pm 0.31 \log _{10} \mathrm{cfu} / \mathrm{ml}$ (Table 1).
Salmonella spp was detected in few samples. The contamination might be due to poor hygienic conditions, presence in food can cause abdominal clamps, fever and vomiting (Mankee et al. 2003). Salmonella presence is of concern in spices as the commodity is added in sufficient quantities to grilled meat for public consumption.

Clostridium perfringens can be found in dust, soils, vegetation among others environment media. Clostridium perfringens were not detected in any of the 20 samples. This might be attributable to poor growth parameter like favourable temperature. Since, its ability to grow in food is largely dependent on storage temperature (European Food Safety Authority 2004). This finding collaborate with that of Gardenguides (2002) that reported limited or no Clostridium perfringens count in spice in Australia. This seems to pose no risk to public health, however at slightly conducive temperature spore germination and cell multiplication can occur.

Similar studies conducted on spice used for selling local meat (kilichi) in Northern Nigeria revealed that the spices were greatly contaminated with E. coli, Salmonella spp and Clostridium spp (Shamsuddeen 2009). Sagoo et al. (2009) also isolated high counts of Clostridium perfringens and $E$. coli from spice and herb in United Kingdom which have potential public health risk. Spices have been associated in large scale outbreaks of food borne illnesses (Gustavsen and Breen 1984), the impact of pathogenic contaminated spice on incidence of food borne illnesses in Ghana cannot be override. The contamination of spices can be attributed to many factors. Since, Banerjee et al. (2003) suggested that spices such as curry powder, thyme, white pepper, paprika are subjected to microbial contamination at various stages of preparation. Equipment and food handlers have also been associated with contamination of food with various types of etiologic agent (Moro et al. 2001).

\section{Possible sources of contaminants in spices}

The study revealed that most vendors buy spices such as pepper, ginger, curry powder, paprika, nutmeg, chilli pepper (all in powdered form) from market and are then mixed in a plastic container. It was observed that vendors mixed spices with their bare hands without wearing hand groves and the prepared spices are left uncovered in the plastic container at the site. This exposes spice to contaminant such as dust, atmospheric particles and airborne microbes.

The study revealed that only one vendor out of five vendors had obtained permits from the Ghana Standard Board and Ghana Tourism Authority. Some reasons for not having permits were due to lack of funds and some vendors not aware that they needed to work with permits. Four out of five vendors had no formal education this might have influenced vendors' consciousness on personal hygiene, food handling and processing techniques. This according to 
Barro et al. (2006), Mensah et al. (2002) and Bryan et al. (1997) are possible means of transmitting pathogens into foods. Pesewu et al. (2014) and AmponsahDoku et al. (2010) attested that substantial persistence and proliferation of bacteria from food production/ processing to consumption is a reflection of poor sanitary and food handling practices, and conditions at various stages of the chain.

Spice handlers should adopt and practice good handling processes to ensure food safety for consumers. The levels of some pathogenic bacteria are not acceptable as the pose serious health implication. This is similar to earlier report by Addo (2005) that there is serious health implication in the consumption of spices on the market.

In Tamale, it is evident that most food vendors are challenged with exogenous factors such as lack of public infrastructures for food vendors to comply with standard hygienic practices (such as clean water sources, public toilets), inadequate waste disposal service, poor sanitary conditions at vending sites (for example dust from dirt roads, open-air sewages, traffic fumes), poor storage conditions, contaminated inputs from farmers and market sellers, and unclean transportation conditions. These findings are echoed by FAO (2016). Tomlins and Johnson (2004) reported that street food pollution can partly originate from raw materials from rural small holders. Also, poor management of markets environment in Ghana has been linked as major cause of food contamination by Soriyi et al. (2008). Most fresh foods especially fermented food like beef and fish are highly vulnerable to pathogenic bacteria invasion and food poisoning.

Statistically, pathogenic bacteria count from the various selected sites is not significant difference (Table 2). The correlation matrix of bacteria count in spices demonstrates no interrelationships between pathogenic bacteria study. Hence, source of contamination of the pathogens is different, affirming the multiple sources of contamination of the spices observed.

Table 2 Comparative analysis of bacteria pathogens count

\begin{tabular}{lllllll}
\hline ANOVA & \multicolumn{1}{c}{$\begin{array}{l}\text { Sum of } \\
\text { Squares }\end{array}$} & df & Mean Square & F & Sig. \\
\hline TC & Between Groups & 467.3 & 4 & 116.83 & 0.52 & 0.72 \\
& Within Groups & 3369.5 & 15 & 224.63 & & \\
FC & Between Groups & 68853.3 & 4 & 17213.33 & 1.23 & 0.34 \\
& Within Groups & 210109.5 & 15 & 14007.3 & & \\
EC & Between Groups & 607037.8 & 4 & 151759.5 & 1.83 & 0.18 \\
& Within Groups & 1246760 & 15 & 83117.33 & & \\
SS & Between Groups & 18.22 & 4 & 4.56 & 0.67 & 0.63 \\
& Within Groups & 102.64 & 15 & 6.84 & & \\
\hline
\end{tabular}

\section{Conclusion}

The study profiled some pathogenic bacteria on common spices used for grilling meat in Tamale. People have the right to consume safe and suitable food. The study showed that mixtures of spices were contaminated with some pathogenic bacteria. Salmonella spp and Escherichia coli are potential enteric pathogens. There is a possible risk to public health associated with consumption of spicy meat from the selected joints. The possible sources of spice contamination include storage equipment, handling, unhygienic surroundings, vehicular transmission, atmospheric particles and airmicrobes. The consumption of meat spiced with these contaminated spices can lead to health related problems such as cholera, diarrhoea, stomach cramps, typhoid fever and dysentery. It is recommended that periodic sanitary inspection and certification of vendors by regulatory body is absolutely necessary to ensure consistency.

\section{Acknowledgements}

The authors are grateful to all staff of CSIR- Water Research Institute, Tamale for their timely analysis of the samples.

\section{Funding}

The authors self-funded study from collection, analysis and interpretation of data and to the final writing of the manuscript.

\section{Authors' contributions}

$\mathrm{NB}, \mathrm{ASA}, \mathrm{ABD}$ have contributed in the study conception and design, data acquisition, and analysis and interpretation of data. SJC and SM participated in intellectual helping in different stages of the study. NB, ABD, SJC and SM participated in drafting of manuscript and preparation of final version. All Authors have read the manuscript and have agreed to submit it in its current form for consideration for publication. All read and approved the final manuscript.

\section{Competing interests}

The authors of this research paper have no competing interests.

\section{Publisher's Note}

Springer Nature remains neutral with regard to jurisdictional claims in published maps and institutional affiliations.

\section{Author details}

'Department of Ecotourism and Environmental Management, Faculty of Natural Resources and Environment, University for Development Studies, Tamale, Ghana. ${ }^{2}$ Department of Biotechnology, Faculty of Agriculture, University for Development Studies, Tamale, Ghana. ${ }^{3}$ Ghana Integrated Water Sanitation and Hygiene World Vision, Tamale, Ghana.

Received: 11 January 2017 Accepted: 16 May 2017

Published online: 25 May 2017

\section{References}

Abankwa V, Grimard A, Somer K, Kuria F. United Nations Human Settlements Programme (UNHABITAT). 2009. Available: www.unhabitat.org/pmss/ getElectronicVersion.aspx?nr=2929. Accessed on 9 September 2016.

Addo AA. Premilinary studies on the microbiological and nutrient quality of three local spices on the Ghanaian market and the control of resident microflora by gamma irradiation: BSc. Hons Dissertation, Department of Botany, University of Ghana, Legon; 2005. p. 68

Ahene RE, Odamtten GT, Owusu E. Fungal and bacterial contaminants of six spices and spice products in Ghana. Afr J Environ Sci Technol. 2011;5(9):633-40.

Alam-Khan K, Abrahem M. Effect of irradiation on quality of spices. Int Food Res J. 2010;17:825-36.

American Public Health Association. Standard Methods for the Examination of Water and wastewater. 20th Edition, American Public Health Association, 
American Water Works Association, Water Environment Federation. USA: United Book Press, Inc; 2008.

Amponsah-Doku F, Obiri-Danso K, Abaidoo RC, Drechsel P, Kondrasen F. Bacterial contamination of lettuce and associated risk factors at production sites, markets and street food restaurants in urban and peri-urban Kumasi, Ghana. Sci Res Essays. 2010:5(2):217-23.

Banerjee M, Sarkar PK. Microbiological quality of some retail spices in India. Food Res Int. 2003;36:469-74

Barro N, Bello AR, Savadogo A, Ouattara CAT, Ilboudo AJ, Traore AS. Hygienic status assessment of dish washing waters, utensils, hands and pieces of money from street food processing sites in Ouagadougou (Burkina Faso). Afr J Biotechnol. 2006;5(11):1107-12.

Bruce J, Boschi-Pinto C, Shibuya K, Black R. WHO's estimates of the causes of death in children. Lancet. 2005;365:1147-52.

Bryan F, Jermini M, Schmitt R, Chilufya E, Mwanza M, Matoba A, Mfume E, Chibiya $H$. Hazards associated with holding and reheating foods at vending sites in a small town in Zambia. J Food Prot. 1997;60:391-8.

Buckenhuskes HJ, Rendlen M. Hygienic problems of phytogenic raw materials for food production with special emphasis to herbs and spices. Food Sci Biotechnol. 2004;13:262-8.

Centre for Disease Control (CDC). Diseases from imported food on the rise. 2012.

Debs-Louka E, El Zouki J, Dabboussi F. Assessment of the microbiological quality and safety of common spices and herbs sold in Lebanon. Journal Food Nutrition and Disorder. 2013;2(4):1-6.

European Food Safety Authority. Opinion of the scientific panel on biological hazards on a request from the commission related to Clostridium spp. in foodstuffs. EFSA J. 2004;199:1-65.

European Union (EU). Bacteriological safety and toxicological safety of dried herbs and spices. EU coordinated programme for the official control of foodstuffs 2004. 2004. p. 1-38. 3rd Trimester National microbiological Survey 2004 (04NS3).

FDA (Food and Drug Administration). 2010 Retail meat report national antimicrobial resistance monitoring system. Rockville: Food and Drug Administration; 2011.

Food and Agriculture Organization of the United Nations. Street food in urban Ghana; a desktop review and analysis of findings and recommendations from existing literature. In: Stefano Marras Mohamed A, editor. Food and Agriculture Organization of the United Nations Accra. 2016.

Ghana Statistical Service. Population census 2010. 2012. Available at www. ghanadistrict.com. Accessed on 6 June 2016.

Gustavsen S, Breen O. Investigation of an outbreak of Salmonella oranienburg infections in Norway, caused by contaminated black pepper. Am J Epidemiol. 1984;119(5):806-12.

Mankee A, Ali S, Chin A, Indalsingh R, Khan R, Mohammad F, Reheman R, Sooknanan S, Tota-Maharaj R, Simeon D, Adesiyun A. Bacteriological quality of doubles sold by street vendors in Trinidad and the attitudes, knowledge and perceptions of the public about its consumption and health risk. Food Microbiol. 2003;20:631-9.

Menlove A, Sainsbury J. The microbiological safety and quality of ready meals: ready meal technology. UK: Leather head Publishing; 2002

Mensah P, Yeboah-Manu D, Owusu-Darko K, Ablordey A. Street foods in Accra Ghana: how safe are they? Bull World Health Organ. 2002;80:546-54.

Moro D, Oludmo AO, Salu OB, Famurewa O. Carriage of enteric pathogens among students of a tertiary institution in Lagos, Nigeria. JR Rev Se. 2001;2:73-6.

Pesewu GA, Agyei JN, Gyimah KI, Olu-Taiwo MA, Osei-Djarbeng S, Codjoe FS, Ayeh-Kumi PF. Bacteriological assessment of the quality of raw-mixed vegetable salads prepared and sold by street food vendors in Korle-Gonno, Accra Metropolis, Ghana. J Health Sci. 2014;2:560-6.

Sádecká J. Irradiation of spices - a review. Czech J Food Sci. 2007;25:231-42.

Sagoo SK, Little CL, Greenwood M, Mithani V, Grant KA, McLauchlin J, de Pinna E, Threlfall EJ. Assessment of the microbiological safety of dried spices and herbs from production and retail premises in the United Kingdom. Food Microbiol. 2009;26(1):39-43.

Shamsuddeen U. Microbiological quality of spices used in the production of kilishi, a traditionally dried and grilled meat product. Bayero Pure Applied Science. 2009;2:66-9.

Soriyi I, Agbogli HK, Dongdem JT. A pilot microbial assessment of beef sold in the Ashaiman market, a suburb of Accra, Ghana. Afr J Food Agric Nutr Dev. 2008;8(1):91-103

Srinivasan K. Role of spices beyond food flavoring: nutraceuticals with multiple health effects. Food Rev Intl. 2005;21:167-88.
Tomlins Kl, Johnson PNT. Developing food safety strategies and procedures through reduction of food hazards in street-vended foods to improve food security for consumers, street food vendors and input suppliers. Crop Post harvest Programme (CPHP) Project R8270. Funded by DFID. Ghana: Natural Resources Institute, UK \& Food Research Institute; 2004.

WHO. Food safety: what you should know. World Health Day: 7 April 2015 SEANUT-196 Distribution: General World Health Organization. 2015.

Zwietering MH, Jacxsens L, Membre JM, Nauta M, Peterz M. Relevance of microbial finished product testing in food safety management. Food Control. 2016;60:31-43

\section{Submit your manuscript to a SpringerOpen ${ }^{\circ}$ journal and benefit from:}

- Convenient online submission

- Rigorous peer review

- Open access: articles freely available online

- High visibility within the field

- Retaining the copyright to your article

Submit your next manuscript at $\boldsymbol{\nabla}$ springeropen.com 